\title{
Evaluating the We b Presence of Voluntary SECTOR ORgaNIZATIONS: An Assessment of Canadian We b Sites
}

\author{
WENDY CUKIER \\ CATHERINE A. MIDDlETON
}

\begin{abstract}
In recent years, considerable attention in Canada has been focused on strengthening relationships between the voluntary sector, government and industry. Information technology is an important tool for the sector, but systems are often difficult and costly to purchase and maintain-particularly for small- and medium- sized groups. Unlike e-business and the private sector, little attention has been paid to how the Internet can be used in the voluntary sector. This article addresses three specific research questions: 1) How are national Canadian voluntary sector organizations using Web sites? 2) How well-designed are these Web sites in terms of usability and aesthetics and 3) How can Canadian voluntary organizations improve their Web sites to meet organizational objectives?

Some 184 English language, national Canadian voluntary organizations' Web sites were rated, using a standardized tool to assess organizational objectives and to evaluate functionality, navigation and aesthetics. These sites currently offer limited functionality, and many are not well-designed. The article draws lessons from information technology theory and practice to demonstrate how the functionality and design of voluntary sector Web sites (in Canada and el sewhere) can be improved, to better support organizational objectives and to reduce the "digital divide" between the profit and nonprofit sectors.
\end{abstract}

Wendy Cukier is a professor in the School of Information Technology Management, Ryerson University, Toronto, Ontario, Canada M5B 2K3. wcukier@compuserve.com.

Catherine A. Middleton is a professor in the School of Information Technology Management, Ryerson University, Toronto, Ontario, Canada M5B 2K3. cmiddlet@ryerson.ca. 
The precise definitions of the "nonprofit sector," the "voluntary sector" or the "third sector" have been the subject of extensive debate in the literature. These terms are often used interchangeably, despite the fact that each term has a precise meaning. The nonprofit sector is large and diverse, encompassing nonprofit institutions, such as hospitals and schools; professional associations; and a host of community and public interest organizations. Febbraro, $\mathrm{Hall}$ and Pargmegiani (1999) suggest that the voluntary sector is most appropriately defined as including both nonprofit and voluntary organizations. They identify five key defining characteristics of nonprofit/voluntary organizations as follows: (1) organized, (2) private, (3) self-governing, (4) voluntary and (5) not involved with distributing profits.

This article focuses on selected, national, voluntary organizations in Canada. Professional associations, while a significant part of the sector, are excluded. In recent years, awareness of the importance of the voluntary sector to the Canadian economy and society has increased. It has been estimated that $12 \%$ of the country's GDP passes through its estimated 200,000 nonprofit organizations (Stewart, 1996), accounting for around $5 \%$ of the national labour force.

Moreover, the sector is growing quickly. In addition to paid labour, the sector depends on a vast army of volunteers, whose donated time is estimated at one billion hours of labour-the equivalent of half a million full-time jobs (Duchesne 1989). However, a variety of changes, including government downsizing, have simultaneously increased the demands on the sector and reduced traditional sources of revenue.

Adoption of information technology (IT) has the potential to improve productivity and service provision in the voluntary sector. Although considerable attention has focused on the emergence of "e-business" and the use of the Internet in the private sector, less attention has been paid to how the Internet is and can be used by the voluntary sector.

It has been suggested that rapid technol ogical change is exacerbating the pressures faced by nonprofit organizations (VSI 2002). While creating new opportunities, technology also presents an enormous risk, because of the costs to develop and maintain IT systems. The "digital divide" implies more than just access to technology; it also involves the skills, knowledge, control and resources needed to use it effectively (Burt and Taylor 2000; Clement and Shade 2000). The specter of a growing "digital divide" has been identified as a critical issue in the sector in at least three ways:

1) From the perspective of information communities served-the information technology "haves" and "have nots" (Servon and Nelson 2000),

2) The growing gap within the sector, particularly between large and small organizations (VSI 2002), and

3) The difference between the nonprofit sector and for-profit firms, most pronounced in countries such as the United States where for-profit and 
nonprofit organizations "compete" in human services and health care markets (Salamon 2002).

In Canada, where education, healthcare and a substantial proportion of social services are provided by public institutions, this last form of "competition" is perhaps less acute than it is in the US. Nevertheless, competition between the nonprofit and private sectors is evident, for example social marketing programs pit community organizations against private sector companies on issues such as health promotion, injury prevention or the environment (Andreasen 1995).

In the past, considerable attention has focused on access to the "public sphere" and access to the mass media by nonprofit organizations (Curran 1991; Phelan 1991). More recently, attention has shifted to how nonprofit organizations participate in the digital age. Some suggest that the Inter net provides opportunities for a wider range of players, large and small, to participate in the public sphere, creating a new form of "tele-democracy" or "digital democracy" (Servon and Nelson 2000). Others suggest that "the only question is how fast and extensively large corporations will move in reconsolidating their predominance and control " of both the technology and content (Lorimer and Gasher 2000). Regardless of the assumptions about the value or importance of information technology to voluntary organizations, understanding how voluntary organizations use IT and how well they use it is an important contribution to these discussions.

The Canadian voluntary sector is consider ed to be "one of the most connected in the world" (Pargmegiani and Sachdeva 2000), yet there is very little current academic research that explores how Canadian vol untary sector organizations are actually making use of such Internet connectivity. One survey indicated that $66 \%$ of Canadian charitable organizations believe that "the Internet is changing the way voluntary organizations are operating" (EKOS Research Associates 2001). It is generally accepted that access to information technologies and the Internet will be of benefit to organizations in the voluntary sector (Burt and Taylor 2000; Eisner et al. 2001; National Council of Nonprofit Associations 1997; Park 2001). It is also evident, however, that nonprofit organizations have yet to fully realize the benefits of adopting I nternet and other information technologies (EKOS Research Associates 2001; Independent Sector 2001).

This article investigates the Web presence of voluntary sector organizations in Canada. It addresses three specific research questions: 1) How do Canadian voluntary sector organizations use Web sites? What functions are supported? What services are offered? 2) How well-designed are the Web sites of Canadian voluntary organizations in terms of usability and aesthetics? and 3) How can Canadian voluntary sector organizations improve their Web sites to meet their organizational objectives? 


\section{LiterATURE ReVIEW}

To date, most of the research seeking to understand how the voluntary sector uses information technol ogy has been done by surveying organizations. Such surveys offer very basic findings and provide limited insights beyond the adoption rates of specific information technologies. For example, a survey conducted for Independent Sector and IT-provider Cisco Systems by Princeton Survey Research Associates (2001) studied 200 executives in "human service" organizations and reported that $49 \%$ of those surveyed had Web sites and $52 \%$ had an office network. Saxton and Game (2001) reported findings from a survey of 75 organizations in the UK, and EKOS Research surveyed 917 organizations in Canada. As is common in these studies, the EKOS study offered aggregatelevel data only, and it did not assess how individual organizations are using their Web sites. The initial data showed that many Canadian voluntary sector organizations are creating and using Web sites. As might be expected, the EKOS data showed that Web presence is related to organizational revenue: $60 \%$ of organizations with annual revenues in excess of $\$ 500,000$ currently have Web sites compared to only $24 \%$ of those with revenues less than $\$ 100,000$ (EKOS Research Associates 2001).

Although nonprofit organizations' corporate objectives differ fundamentally from those of for-profit organizations, the basic organizational processes and functions of both organization types do not. As Drucker (1990) states, "the source of its money is probably the greatest single difference between the nonprofit sector and business and government" (p. 56). In contrast to the for-profit sector, nonprofits may provide excellent services that are in high demand but that do not generate sufficient revenue to survive. This is because many voluntary organizations provide services to one set of "clients" (recipients of their services), while generating revenue from another (for example, government or donors).

A considerable amount of research examined the ways in which corporate concepts, such as marketing, apply in the context of nonprofit organizations (Kotler and Zaltman 1971; Lefebvre and Flora 1988; Lovelock and Weinberg 1989). In addition, many studies have explored definitions of "excellence" or "performance" of voluntary organizations and their link to organizational strategies, processes and practices including leadership, marketing, resource development and the like (Beilefield 1994; Croker 2001; Padanyi and Gainer 2001).

In the information technology field, considerable research has examined the role of technology generally and Web sites in particular to support corporate objectives (e.g., Kelsey 2002). Several studies of "e-business," for example, have attempted to develop frameworks for understanding the ways in which technology supports corporate value chains and the ways in which the Internet has changed the face of competition. In a 
recent article, Porter (2001) examined applications of the Internet in the corporate value chain, and analogous opportunities can be identified for nonprofit organizations. The application of Porter's competitive strategy model has been shown to be valuable for nonprofit strategy development and implementation (Lindenberg 2001). Typically, for example, nonprofits have a range of activities associated with inbound logistics-acquiring materials and information on how to develop "products" and "services." Most are essentially service providers; the services they develop and distribute may include information provision, mobilization, behavior change, advocacy, direct services and the like. Nonprofits must deliver these services to "clients," even though the recipients of these services are often not those who pay for the services rendered.

J ust as "social marketing" has been explored as a means by which nonprofit organizations may obtain their objectives, "persuasive technologies" have been explored in the context of their effectiveness in promoting change (Fogg 1999). For example, King and Tester (1999) assess trends and examples of the use of persuasive technologies in health, safety and environment applications. Their findings emphasize ways in which these technologies may achieve their ends: simulated experiences, surveillance, "environments of discovery," virtual goups of communities and personalization. Berdichevsky and N eunschwander (1999) emphasize the growing importance of considering ethical issues in nonprofits and, in particular, the importance of privacy, disclosure, accuracy and "the golden rule." Similarly, a study of mental health information on the Internet (Schwartz and Christakis 2001) outlined a number of guiding principles to protect and promote the interests of those seeking information on the Internet, thus reinforcing the importance of attention $\mathbf{b}$ privacy, disclosure, cultural appropriateness and accessibility.

Increasingly, attention has been focused on exploring how Web site effectiveness, notably functionality and design, can be evaluated (Madsen 1999; Nielsen and Tahir 2001; Ceaparu and Shneiderman 2002). In addition to developing and applying standards for navigation, attention has focused on the aesthetic aspects of design and some have noted the ongoing debate between informational and experiential approaches to interface design (Seo 2002). A number of assessment methods to evaluate Web site quality and effectiveness have been devel oped (see Barnes and Vidgen 2000; Katerattanakul and Siau 1999; Schubert and Dettling 2002; Zhang and von Dran 2001) and applied in the corporate context. Much work has also been done to assess the accessibility of Websites for a wide variety of users (See the Universal Usability in Practice project, at http://www.otal.umd.edu/uupractice/index.html and the Universal Usability Guide at http://www.universalusability.org). Some research addresses the specific usability issues faced by people with disabilities (see Hung 2001 for a review of issues for people with visual disabilities; and Deng 2001 for a discussion of issues related to mobility impairment). 
Voluntary organizations were among the early adopters of electronic communications networks to support their efforts, and the role of the Internet has been well understood as an important means of grass roots organizing and as an advocacy tool (for example, Naughton 2001). More recently, studies have also been undertaken to identify the specific application of information technology in the nonprofit sector, for example, in improving management control and accountability (Nitterhouse 1999; Prives 2000); supporting volunteers (Mcduff et al. 2001); promoting "e-advocacy" (Krehely and Montilla 2001); improving organizational effectiveness (Pollak and Lampkin 2001) and enhancing service provision (Creaturo 2001). In addition, private sector consultants offer advice on a wide range of applications from grant management to "e-fundraising." However, the work on information technology is still in its infancy, and much of it is descriptive. With the exception of some work on government Web sites (e.g., Gant and Gant 2002), there has been scant attention paid to systematic analysis of Web sites developed for and used by non-business organizations.

As the review of the literature shows, theoretical frameworks and approaches used in the private sector (e.g., strategy, organizational theory, leadership, marketing, financial analysis and reporting) have been adapted to the nonprofit sector. Information technology has the potential to further organizational objectives in the nonprofit sector, just as it has in the for-profit sector. Yet, relatively little has been written on the strategic application of information technology in general or on the use of Websites in particular. By integrating theory on IT strategy and Website design with data on current voluntary sector practices, this article suggests ways in which voluntary sector organizations (in Canada and beyond) can make better use of Internet technologies to achieve their objectives.

\section{METHODOLOGY}

Data were collected from $184 \mathrm{Engli}$ ish-language, Canadian voluntarysector Web sites, drawn from a list on the Canadian Centre for Philanthropy Web site available at http://www.ccp.ca/information/links.html. (See Appendix A for a complete list of Web sites included in this study.) Web sites for this study were selected from Canada-wide organizations rather than from local organizations. Where there were several affiliates of the same organization (for example, provincial or local chapters), only the national Web site was used.

As Table 1 illustrates, the organizations included in this study represent voluntary organizations from a variety of sectors. Health-related Web sites accounted for more than one-fifth of those considered (21\%), followed by environmental Web sites (13\%). To a certain extent these categorizations are subjective, and many organizations could be placed in more than one category. For example, Project Ploughshares is a faith-based organization, but its principal objective is to promote peace. The Council of Canadians has some 
TABLE 1: DESCRIPTION OF SAMPLE BY TYPE OF ORGANIZATION (DEFINED BY SECTOR)

\begin{tabular}{|lcc|}
\hline Sector & \# of Organizations & \% of Organizations \\
\hline Arts & 11 & $6.0 \%$ \\
Devel opment & 9 & $4.9 \%$ \\
Education & 8 & $4.3 \%$ \\
Environment & 24 & $13.0 \%$ \\
Equality Seeking/Human Rights & 5 & $2.7 \%$ \\
Faith & 7 & $3.8 \%$ \\
Health & 39 & 21.2 \\
J ustice & 3 & $1.6 \%$ \\
Other & 10 & $5.4 \%$ \\
Peace & 2 & $1.1 \%$ \\
Philanthropy & 12 & $6.5 \%$ \\
Political & 13 & $7.1 \%$ \\
Research & 4 & $2.2 \%$ \\
Social Services and Support & 17 & $9.2 \%$ \\
Youth Services and Support & 12 & $6.5 \%$ \\
TOTAL & $\mathbf{1 8 4}$ & $\mathbf{1 0 0 \%}$ \\
\hline
\end{tabular}

initiatives, which might be considered health- or environment-related (for example, regarding bovine growth hormones); however, it was founded with the expressly political objective of opposition to free trade.

The researchers attempted to categorize according to the principal sector rather than according to an organization's function. Although most voluntary organizations have some political aims and advocacy functions, "political" groups pursue explicitly political objectives or represent the interests of a particular interest group. Equality-seeking/human rights groups also have political aims, but they are generally regarded as advocating on behalf of populations facing forms of discrimination prohibited under the Canadian Charter of Rights and Freedoms or Human Rights Code or in accordance with international standards for human rights and humanitarian law.

The authors modified an assessment tool from Grant and Prescod (2001) for examining vol untary sector Web sites. A team of student research assistants visited each of the Web sites within a two-week period. Data were collected using an objective measurement tool, components of which are described in each section below. For example, in assessing features available on the site, a series of very specific questions - each with a "yes" or "no" answer was investigated.

The research team collected data by directly examining Web sites; data were not collected about Web sites by surveying organizations. This is an important distinction, because data gathered from individual organizations are 
less likely to be consistent than data collected by a small number of researchers using an objective set of guidelines. At the same time, research that would include interviews with organizations would enrich the study.

\section{RESULTS}

Question One: How are Canadian voluntary sector organizations using Web sites? What functions are supported? What services are offered? Are Canadian voluntary sector organizations establishing and using Web sites? After a review of the literature on "e-business" (Grant and Prescod 2001; Porter 2001), supplemented by the literature on nonprofit and voluntary sector organizations (VSI 2001; Burt and Taylor 2001; Kerr 2002), this study identified the following eight different activities and services that can be delivered to Web site users by voluntary organizations:

1) provision of information,

2) organizational promotion,

3) fundraising,

4) advocacy support,

5) member support,

6) media support,

7) community development and

8) volunteer recruitment

This study did not address other aspects of the supply chain, such as links to suppliers or the use of intranets.

The initial results show that only information provision and organizational promotion are widely available, both offered by more than $80 \%$ of the sites. In contrast, fewer than $3 \%$ of sites offer full support for advocacy (e.g., online petitions or direct email links to politicians). Approximately $35 \%$ of sites offer some support for online fundraising (e.g., information to facilitate donations or acceptance of online donations).

A summary of findings is presented in Table 2 . Note that these results were obtained by simple observation of features on the site, which were either present or absent at the time of data collection.

Provision of Information Content: Most of the Web sites' principal functions were related to information for various publics-potential clients, potential donors and the media, among others. Sites included the following: general content about the organization (89\%), links to other organizations (72\%), links to government sources (50\%), "promotional" material intended to persuade $(82 \%)$ and media support (49\%). Almost half provided copies of press releases and media briefs. 
TABLe 2: Summary OF Features PRESENT in SAMPLEd Web Sites

\begin{tabular}{|c|c|c|}
\hline Web Site Feature & \# of Organizations & $\%$ of Organizations \\
\hline \multicolumn{3}{|l|}{ Basic Information Provision } \\
\hline $\begin{array}{l}\text { General background on organization (e.g., information } \\
\text { for media) }\end{array}$ & 164 & $89 \%$ \\
\hline Information for partners & 158 & $86 \%$ \\
\hline Information regarding services & 161 & $88 \%$ \\
\hline \multicolumn{3}{|l|}{ Promotional Activities } \\
\hline $\begin{array}{l}\text { Promotional elements designed to specifically promote } \\
\text { the organization and its objectives }\end{array}$ & 151 & $82 \%$ \\
\hline \multicolumn{3}{|l|}{ Fundraising } \\
\hline Downloadable forms & 60 & $33 \%$ \\
\hline Online donations & 66 & $36 \%$ \\
\hline Online payment (either direct or through a third party) & 49 & $27 \%$ \\
\hline \multicolumn{3}{|l|}{ Advocacy Support } \\
\hline Lists of politicians & 6 & $3 \%$ \\
\hline Information regarding advocacy issues & 68 & $37 \%$ \\
\hline Sample letters & 11 & $6 \%$ \\
\hline Allows online email to politicians & 5 & $3 \%$ \\
\hline Online petitions & 4 & $2 \%$ \\
\hline \multicolumn{3}{|l|}{ Member/User Support } \\
\hline Online support & 64 & $35 \%$ \\
\hline Feedback forms & 17 & $9 \%$ \\
\hline Links to government sources & 91 & $50 \%$ \\
\hline Links to other organizations & 132 & $72 \%$ \\
\hline \multicolumn{3}{|l|}{ Media Support } \\
\hline Online press releases & 90 & $49 \%$ \\
\hline Briefing materials & 77 & $42 \%$ \\
\hline \multicolumn{3}{|l|}{ Volunteer Rearuitment } \\
\hline Volunteer recruitment activity within the last week & 2 & $1 \%$ \\
\hline Volunteer recruitment activity within the last month & 2 & $1 \%$ \\
\hline $\begin{array}{l}\text { More than one month since last volunteer recruitment } \\
\text { activity }\end{array}$ & 32 & $17 \%$ \\
\hline \multicolumn{3}{|l|}{ Currency of Site } \\
\hline Evidence of updating within last 24 hours & 12 & $7 \%$ \\
\hline Evidence of updating within last 3 days & 21 & $11 \%$ \\
\hline
\end{tabular}


The content of the sites was rated on a five-point scale. No information was obtained regarding the role of the Web site in an organization's overall communication strategy or the level of usage or impact of the Web sites on an organization's target audiences. About half the sites were judged "good" or "excellent" in terms of the quality of information, range of information and effective communication of a message (see Table 6 for more detail). Half the sites were considered to be "just brochureware," meaning they were essentially electronic distribution mechanisms for print materials. This, of course, is a significant benefit for organizations, allowing them to communicate with potential supporters at a fraction of the costs of advertising, direct mail or telemarketing.

Online Support for Fundraising: When assessing the extent to which Canadian voluntary sector Web sites are able to offer support for fundraising, three features were considered: 1 ) Does the site provide downloadable forms for making donations? 2) Can people signal an intention to donate online? and 3) Can payment be made online, either directly or through a third party? The analysis shows that almost half of the sites (47\%) offered no online support for fundraising, $25 \%$ of sites made one fundraising activity available, $16 \%$ had two activities enabled, while only $13 \%$ supported al I three fundraising activities. (See Table 3.)

Table 4 bel ow lists the 24 organizations that currently provide support for all three fundraising activities. Currently, it does not appear that any specific type of voluntary organization is particularly good at online fundraising. Instead, it seems that organizations across the voluntary spectrum are only now starting to experiment with support for online fundraising.

Support for Advocacy Activities: Canadian charitable organizations are restricted in the amount of political lobbying they may undertake (no more than $10 \%$ of resources may be spent on this activity). Nevertheless, some advocacy is a core function of many voluntary groups. Five different types of advocacy activities present on the Web sites were assessed:

1) Provision of a list of politicians (site visitors could find out how to voice their concerns to elected officials),

2) Information regarding advocacy issues,

3) Sample letters,

4) Direct email links to politicians and

5) Online petitions.

As Table 5 illustrates, $62 \%$ of sites surveyed had no facilities to provide advocacy support. Given that many of the organizations have some advocacy component to their mission, it appears that most have not yet figured out how to use the Web to support advocacy. 
TABLE 3: FUNDRAISING ACTIVITIES

\begin{tabular}{|ccc|}
\hline \# Fundraising Activities & \# Organizations & \% Organizations \\
\hline 0 & 86 & $47 \%$ \\
1 & 45 & $24 \%$ \\
2 & 29 & $16 \%$ \\
3 & 24 & $13 \%$ \\
\hline
\end{tabular}

TABLE 4: ORGANIZATIONS OfFERING THREE, ONLINE FUNDRAISING ACTIVITIES

\begin{tabular}{|ll|}
\hline Organization Name & Category \\
\hline AIDS Committee of Toronto & health \\
Association of Fundraising Professionals & equality seeking/human rights \\
Asthma Society of Canada & other: fundraising \\
Canada Family Action Coalition & health \\
Canada World Youth / J eunesse Canada Monde & political \\
Canadian Parks and Wilderness Society & youth services and support \\
Canadian Red Cross & environment \\
Canadian Special Olympics & health \\
Canadian Women's Foundation & other: sports \\
CARE Canada & philanthropy \\
Center For Social J ustice & development \\
Children's Aid F oundation & equality seeking/human rights \\
Children's Wish Foundation of Canada & philanthropy \\
Christian Blind Mission International Canada & philanthropy \\
Christian Children Fund of Canada & health \\
Council For Canadian Unity & youth services and support \\
Council of Canadians & political \\
David Suzuki Foundation & political \\
Federation of Ontario Naturalists & environment \\
Project Ploughshares & environment \\
Prostate Cancer Research Foundation of Canada & peace \\
UNICEF Canada & health \\
World Federation of Hemophilia & youth services and support \\
\hline
\end{tabular}


TABLE 5: ADVOCACY FEATURES

\begin{tabular}{|ccc|}
\hline \# Advocacy Features & \# Organizations & \% Organizations \\
\hline 0 & 115 & $62 \%$ \\
1 & 55 & $30 \%$ \\
2 & 7 & $4 \%$ \\
3 & 3 & $2 \%$ \\
4 & 4 & $2 \%$ \\
5 & 0 & $0 \%$ \\
\hline
\end{tabular}

Question Two: How well designed are the Web sites of Canadian voluntary organizations in terms of usability and aesthetics? Assessments were made on various aspects of the Web sites, including overall attractiveness, effectiveness in communicating the site's "message," as well as the quality and range of the information. In general, the Web sites were found to be competently developed and maintained-that is, obvious mistakes or broken links were reported in only a small percentage of cases. Even though overall site attractiveness is a subjective factor, and aesthetic assessments depend on a wide range of cultural, demographic and individual characteristics, the aesthetic experience is an important factor in attracting and retaining users. As such, specific aspects of design were identified and assessed.

The following factors were considered in assessing overall site attractiveness: 1) Layout of the site (e.g., sites with multiple frames that required scrolling in small portions of the screen were rated lower than those with simple, clean designs that avoided a cluttered appearance), 2) Choice of colors (with a specific focus on readability, e.g., sites with links that were hard to read were rated as less attractive than those with high- contrast colors) and 3) Usage of design features (e.g., sites with flashing and/or scrolling text were generally considered less attractive than those without these elements. Highly rated sites used new design tools like Flash to create animation, rather than relying on basic HTML commands).

When assessing effectiveness in communicating the "message," the assessors were asked whether they could determine the organization's purpose or objectives from the Web site. An excellent site would offer detailed information either on the front page of the site or in a link clearly identified on the front page. Poor sites were ones where even after searching the site, it was still not possible to clearly determine the purpose of the organization.

Quality and range of information were closely related. They were assessed in terms of the level of detail and timeliness of the information provided (e.g., a site promoting events within the next three months would be rated as having good or excellent quality of information, whereas one promoting events that had happened months or years ago would receive a poor or very poor rating), and in terms of the scope of information provided (e.g., Does the site explain what the organization does? Does it list officers of the organization? 
Does it provide contact details? Does it offer examples of what money is used for, if the organization is a fundraising one? Does it explain how to join the organization? Does it list events the organization is planning? Does it provide information for volunteers? Does it provide press releases and information on media coverage of the organization?). Given the different objectives of the various sites assessed, no specific formula was used to calculate quality and range of information ratings. For a site to be rated as excellent in terms of quality of information however, all information on the site had to be judged to be very detailed and current. In contrast, a very poor site had limited information that was very much out of date.

On these factors, the majority of Web sites were rated as "good" or "excellent," as shown in Table 6. Slightly more than half of the sites were rated as "good" (36\%) or "excellent" (19\%) in terms of overall site attractiveness.

Further assessments were made of a variety of Web site usability features including ease of use, navigation and layout. Layout was assessed by page appearance (e.g., a page in which scrolling was required either to see the edge of a graphic or to read a column of text exhibited poor layout) and positioning of information (pages in which graphics overlapped text or pages with important information at the bottom of a long list demonstrated poor layout).

As noted below, options for personalization were found very infrequently. Examples of personalization options included the ability to send a choice of greeting cards from a site, or to create a personal information profile. Personalization options were rated as "good" or "excellent" depending on the ease of use of the features.

The clear navigation feature was assessed in terms of the ease of determining where the site visitor was in the site. "Excellent" and "good" sites included site maps, persistent navigation bars (e.g., list of links that was al ways in the same place on the page, usually at the top, bottom, or on the left-hand side), and distinct colors to distinguish a list of links from links that had been visited. Excellent sites also used roll-over navigation options, where moving the mouse over a link would provide additional information about where the link would lead the user. Sites that actively engaged the visitor induded features like discussion areas or live chats, animated demonstrations or site tours, and quizzes.

Speed of site loading is dependent on a number of factors. Assessors were asked to rateloading speed in relative terms-that is, in relation to their general experiences on the Web. F or example, how did the loading speed of a particular site compare to that of others? Click-throughs to other Web sites were easily identified, and they were assessed according to the variety and quantity of links. Site-searching capability was also easily identified, with most sites either providing excellent search facilities or none at all. Search features of sites with intermediate ratings were hard to find, didn't work at all, or provided ambiguous results. 
TABLe 6: OVerall ASSessment OF Web Site Design

\begin{tabular}{|lccccc|}
\hline Criterion & Very Poor & Poor & Adequate & Good & Excellent \\
\hline Overall Site Attractiveness & $2 \%$ & $14 \%$ & $30 \%$ & $36 \%$ & $19 \%$ \\
Effectiveness in Communicating & $3 \%$ & $17 \%$ & $26 \%$ & $35 \%$ & $19 \%$ \\
"message" & $4 \%$ & $10 \%$ & $32 \%$ & $36 \%$ & $19 \%$ \\
Quality of Information & $5 \%$ & $14 \%$ & $27 \%$ & $34 \%$ & $20 \%$ \\
Range of Information & & &
\end{tabular}

TABLE 7: DESIGN FEATURES

\begin{tabular}{|c|c|c|c|c|c|}
\hline Feature & Very Poor or NA & Poor & Adequate & Good & Excellent \\
\hline Home Page layout & $4 \%$ & $14 \%$ & $30 \%$ & $31 \%$ & $20 \%$ \\
\hline Personalization & $85 \%$ & $7 \%$ & $4 \%$ & $2 \%$ & $2 \%$ \\
\hline Clear navigation at all times & $11 \%$ & $13 \%$ & $16 \%$ & $33 \%$ & $27 \%$ \\
\hline $\begin{array}{l}\text { Active engagement of visitor } \\
\text { (click-on participation features) }\end{array}$ & $44 \%$ & $11 \%$ & $18 \%$ & $21 \%$ & $6 \%$ \\
\hline Speed of load & $3 \%$ & $7 \%$ & $12 \%$ & $34 \%$ & $45 \%$ \\
\hline $\begin{array}{l}\text { Click throughs to other relevant } \\
\text { Web sites (Links) }\end{array}$ & $32 \%$ & $6 \%$ & $14 \%$ & $28 \%$ & $21 \%$ \\
\hline $\begin{array}{l}\text { Site search capability (visible, } \\
\text { functional) }\end{array}$ & $60 \%$ & $4 \%$ & $3 \%$ & $8 \%$ & $25 \%$ \\
\hline
\end{tabular}

Table 7 shows that in terms of overall layout, ease of use, speed of load and limited number of click-throughs, more than half of the websites were rated as "good" or "excellent." However, a smaller percentage of the sites were considered to provide "good" (8\%) or "excellent" (25\%) search capabilities, and very few offered "good" or "excellent" personalization (4\%).

Overall Quality of Design: The design features of each site were identified, using a checklist of nine 'good' design features, and nine 'bad' design features adapted from Grant and Prescod (2001). As shown in Table 8, good design included clear use of color, careful use of scrolling, and provision of different ways to get straight to where the user wants to go on the site. Bad design features, as shown in Table 9, included poor use of graphics, missing and broken links, and the need for multiple clicks to move up or down within the site. Design features were recorded as being present or absent.

A "design score" was calculated to determine the overall design quality of each site. Poor design features were given a negative weighting. Thus a site's design score could range from 9 (all good design features present, no poor design features) to -9 (only poor design features present). The average design score was 
TABLE 8: GOOD DESIGN FEATURES

\begin{tabular}{|lc|}
\hline \multicolumn{1}{|c|}{ Good Design Features } & \% of Organizations \\
\hline Clear use of col or and background & $79 \%$ \\
Good signposts at all times & $70 \%$ \\
Different ways to get straight to where you want to go & $51 \%$ \\
Careful use of scrolling (limited, put important & $54 \%$ \\
information at top, especially links) & \\
Site tour/demo available and useful & $20 \%$ \\
Chance to preview content without & $98 \%$ \\
registration/membership & \\
Bypass graphic downloads to get to needed functions & $17 \%$ \\
Site Map & $30 \%$ \\
Opportunity for Customers/U sers to give feedback & $70 \%$ \\
\hline
\end{tabular}

TABLE 9: BAD DESIGN FEATURES

\begin{tabular}{|c|c|}
\hline Bad Design Web Site Feature & $\%$ of Organizations \\
\hline Need an ID/Registration before any area of the site can be viewed & $1 \%$ \\
\hline $\begin{array}{l}\text { Multiple clicks up/down to get somewhere (i.e., more than } 2 \text { clicks, no "jump" } \\
\text { navigation) }\end{array}$ & $28 \%$ \\
\hline Inability to know where you are in the site layout & $32 \%$ \\
\hline $\begin{array}{l}\text { Dead ends, after several clicks with no new content (perhaps under } \\
\text { construction or no real info) }\end{array}$ & $12 \%$ \\
\hline Missing links messages & $4 \%$ \\
\hline $\begin{array}{l}\text { Inappropriate "M ystery Meat" Links } \\
\text { (user has to guess where the click-throughs are and for what) }\end{array}$ & $8 \%$ \\
\hline $\begin{array}{l}\text { Poor use of graphic intensive techniques } \\
\text { (long load, no bypass, not useful) }\end{array}$ & $21 \%$ \\
\hline $\begin{array}{l}\text { Obvious Carelessness } \\
\text { (e.g., spelling/proofing errors) }\end{array}$ & $5 \%$ \\
\hline $\begin{array}{l}\text { Site is just "brochureware" } \\
\text { (i.e., information only, no additional functionality) }\end{array}$ & $52 \%$ \\
\hline
\end{tabular}

3.3, typically representing a site that had about 5 good design features and 2 poor ones. The 24 sites that had a design score of 7 or higher are listed in Table 10. 
TABLE 10: The TOP-24, WeLL-Designed Sites

\begin{tabular}{|lccc|}
\hline Organization Name & Design score & Good design & Bad design \\
\hline National Ballet School & 9 & 9 & 0 \\
Canadian Women's Health Network & 9 & 9 & 0 \\
National Ballet of Canada & 8 & 8 & 0 \\
Heart and Stroke Foundation of Canada & 8 & 8 & 0 \\
IOF Foresters & 8 & 8 & 0 \\
Canadian Society of Association & & & \\
Executives & 8 & 8 & 0 \\
Children's Aid Foundation & 8 & 8 & 0 \\
Amnesty International Canada & 7 & 7 & 0 \\
Canadian Race Relations Foundation & 7 & 7 & 0 \\
MADD Canada & 7 & 7 & 0 \\
Careers the Next Generation & 7 & 7 & 0 \\
Canadian Nature Federation & 7 & 7 & 0 \\
Canadian Parks and Wilderness Society & 7 & 7 & 0 \\
Nature Conservancy of Canada & 7 & 7 & 0 \\
Osteoporosis Society of Canada & 7 & 7 & 0 \\
Max Bell Foundation & 7 & 7 & 0 \\
CARE Canada & 7 & 7 & 0 \\
Community Foundation of Canada & 7 & 7 & 0 \\
Historica Foundation of Canada & 7 & 8 & 1 \\
Alzheimer Society of Canada & 7 & 8 & 1 \\
J.W. McConnell Family Foundation & 7 & 8 & 1 \\
Ketchum Canada Inc. & 7 & 8 & 1 \\
J ohn P. Robarts Research Institute & 7 & 8 & 1 \\
CUSO & 7 & 8 & 1 \\
\hline
\end{tabular}

Question Three: How can Canadian voluntary sector organizations improve their Web sites to meet organizational effectiveness? This study shows that about half of the Web sites studied in the Canadian voluntary sector organizations are well-designed in terms of functionality, usability and 
aesthetics. However, most sites do not provide those advanced features to engage users that are considered key to "persuasive" technologies.

Research by Zhang and von Dran (2001) applies a model of customer expectations devel oped by a J apanese consultant (Kano et al. 1984) to show that over time, features that were once considered novelties on Web sites (e.g., sophisticated navigation tools, interactive features) become demanded and expected as basic features. This suggests that nonprofits need to be more attentive to design issues.

Voluntary sector organizations understand that it is important to engage their potential Web audiences, but the features that are currently the most widel y available on Canadian voluntary organization sites (i.e., information provision and organizational promotion) are not ones offering much ongoing audience engagement. It is essential to provide features that go beyond the target audience's basic expectations; yet voluntary sector Web sites are not generally doing this. Zhang and von Dran's (2001) research also notes that expectations for site features vary depending upon the purpose of the site. Their findings can be applied to voluntary sector Web sites to determine what features will be most likely to engage their audiences. Voluntary sector organizations can improve their Web presence, by combining a clear understanding of their organizational objectives and functions with sound Web site design principles.

Probably the most striking finding of the study relates to building relationships with users and developing online communication sites. The majority of voluntary Web sites provide opportunities for visitors to ask questions or provide feedback. Most organizations take far too long to respond. Specifically, all sites were sent feedback by the researchers. More than $50 \%$ of organizations took longer than five days to respond to email enquiries. While it is possible that organizations might respond most quickly to messages regarding fund raising and donations, this was not specifically investigated.

Nevertheless, regardless of message content, fast response times are key to building positive relationships with members of the sites' user communities. Someone who sends a general enquiry message might not become a donor or become involved in the organization at all if there is a long response time. It was also found that more than $40 \%$ of sites do not actively engage the user, and less than half allow for any sort of personalization by the user. F ewer than $10 \%$ of the sites provide customized feedback forms, but $70 \%$ do provide the opportunity to contact the organization via email to provide feedback (see Table 11).

\section{Discussion}

This article examines how Canadian voluntary sector organizations are using their Web sites. Drawing on information technology theory and practice, it outlines a number of recommendations to hel $p$ voluntary sector organizations improve their Web sites, so that they can better support their organizational 
TABLE 11: RESPONSE TIME

\begin{tabular}{|lc|}
\hline Response time to email message & \% of Organizations \\
\hline Within 4 hours & $17 \%$ \\
Within 12 hours & $14 \%$ \\
Within 24 hours & $10 \%$ \\
Within 3 days & $9 \%$ \\
More than 5 days & $46 \%$ \\
Email not working/no address & $5 \%$ \\
\hline
\end{tabular}

objectives within the context of an information technology strategy. Like forprofit organizations, voluntary organizations should perform the following:

- Assess the ways in which IT can support processes across the value chain cost-effectively.

- Assess the specific ways in which an Internet/Web strategy should support organizational processes and consider a full range of functions (for example in fundraising and advocacy) to support client relationships, customization, data-collection and data-mining cost effectively.

- Ensure that the communications needs of client groups are well understood and that the Web site is designed to meet those needs.

- Develop an understanding of the principles of good Web design and examine Web design from a user perspective. (Particular attention should be paid to usability but also to the host of ethical issues raised regarding disclosure of information sources, privacy and the like).

- Consider the "competition," exploring other organizations' Web sites, particularly those regarded as exemplary.

- Explore the potential of "persuasive technologies" to address experiential as well as informational aspects of communications via the Internet and Web.

- Ensure the organization's Website is supported appropriately to ensure it delivers upon its potential (e.g., updates, feedback and the like).

The study is limited in a number of respects, and further work is needed to assess the role of IT generally and Web sites particularly. More detailed metrics are available to measure design features of Web sites (Ivory, Hearst and Sinha 2001; Ceaparu and Shneiderman 2002), features assessed subjectively in this study. An investigation of these heuristics would provide new insights related to accessibility and usability of the sites.

In addition, the assessment of functionality, design and usability was conducted without detailed information regarding organizational objectives, 
intended audience or Web-site usage data. Further work is needed to refine the categorization of voluntary organizations in terms of sector, function and size. It is fairly obvious, for example, that large well-funded voluntary organizations are more likely to have the resources and expertise needed to develop, support and maintain a high-quality Web site and necessary information infrastructure than many small voluntary organizations.

It is therefore not surprising to find that many of the organizations that were rated the highest in terms of Web site design are also large, wellestablished voluntary organizations. At the same time, this preliminary review of the data would suggest that many large, well-funded organizations have not done a particularly good job of planning, designing or managing their Web sites. F urther research, using surveys and in-depth interviews with the voluntary organization in question, would also illuminate the objectives and perceived value of these Web sites, their intended users and target audiences, and the actual usage metrics. A more detailed evaluation of a smaller group of voluntary organizations from the perspective of their target audience would provide a more nuanced assessment of their role and effectiveness. Further work may include user surveys and focus groups, for example.

Finally, the field of Web site usability and design remains wide open. In particular, exploring further the relevance of informational versus experiential approaches may be germane within the goals of nonprofit organizations' fundraising, education and advocacy efforts. In addition, further work is needed to explore the assessment criteria that are important to clients and to the public for voluntary organizations-such as accuracy, disclosure of sources and privacy.

Although the "digital divide" normally describes the gap between those who have access to the Internet and those who do not, the very definition of "access" is an issue to be further examined, particularly in terms of its impact on the individuals and organizations participating in the voluntary sector. "Access" is not merely a function of the availability of the technological infrastructure, but also a function of the knowledge, resources and skills needed to use the technology effectively. This study suggests a number of avenues for further research to explore what "access" means in the context of Canada's voluntary organizations and to explore how this "digital divide" is manifested.

\section{REFERENCES}

Andreasen, A. R. 1995. Marketing and Social Change. San Francisco: J ossey Bass.

Barnes, S. J . and Vidgen, R. T. 2000. Webqual: An Exploration of Web Site Quality, Proceedings of the Eighth European Conference on Information Systems. Vienna. 
Beilefield, W. 1994. What Affects Nonprofit Survival? Nonprofit Management and Leadership, 5, p. 19-36.

Berdichevsky, D. and Neunschwander, E. 1999. Towards an Ethics of

Persuasive Technology, Communications of the ACM , 42 (5), p. 51-58.

Burt, E. and Taylor, J . A. 2000. I nformation and Communication Technologies

Reshaping Voluntary Organizations? Nonprofit Management and

Leadership, 11 (3), p. 131-143.

Ceaparu, I . and Shneiderman, B. 2002. I mproving Web-B ased Civic I nformation Access: A Case Study of the 50 US States, Proceedings of the International Symposium on Technology and Society (ISTAS '02) IEE E.

Clement, A and Shade L. R. 2000. The Access Rainbow: Conceptualizing Universal Access to the I nformation/Communication Infrastructure. In Michael Gurstein (ed.) Community Infomatics: Enabling Communities with I nformation and Communications Technologies. Hershey: I dea Group. p. 32-51.

Creaturo, S. M. 2001. The Digital Workforce: How Technology Is Transforming Nonprofit J ob Training Programs, The I mpact of I nformation Technology on Civil Society, Independent Sector Spring Research Forum. Washington, DC.

Croker, G. 2001. Total Quality of Charitable Service: Profiles of Excellence in Christian Relief and Development Organizations. Regent University: Center for Leadership Studies.

Curran, J . 1991. Rethinking Media as a Public Sphere. In Dahlgren, Peter and Sparks, Colin, (eds.) Communication and Citizenship. London: Routledge. p. 27-57.

Deng, Y. 2001. Accommodating Mobility I mpaired Users on Web. Available at: http://www.otal.umd.edu/uupractice/mobility/ Accessed December, 2002.

Drucker, P. F. 1990. Managing the Nonprofit Organizations: Principles and Practices. New York: Harper Collins.

Duchesne, D. 1989. Giving Freely: Volunteers in Canada. Statistics Canada, Labour Analytic Report, Cat: 71-535 No. 4, Ottawa: Ministry of Supply and Services Canada.

Eisner, D., Whitlam, M., Austin, J . and Rogers, S. 2001. Building Communities: Is Technology a Unifying F orce? F acts and Findings, 3 (2), 4. Available at: http://www.independentsector .org/PDF s/factfind4.pdf

EKOS Research Associates. 2001. Survey of Voluntary Organizations. Available at: http://www.volnet.org/EkosHTML/index.htm

F ebbraro, R., Hall, M.H. and Pargmegiani, M. 1999. The Voluntary Health Sector in Canada: Developing a Typology Definition and Classification. Ottawa: Health Canada.

Fogg, B. J . 1999. Persuasive Technologies. Communications of the ACM, 42 (5), p. 27-29. 
Gant, J . P. and Gant, D. B. 2002. Web Portal Functionality and State Government E-Service. In Sprague, R. H., J r. (ed.), Proceedings of the 35th Annual Hawai'i International Conference on System Sciences Waikoloa, HI: IEEE.

Grant, K. and Prescod, F. 2001. Glacier, River or Torrent? The Movement Online of Large Canadian Corporations. Paper presented at the ASAC, London, Canada.

Hung, E. 2001. Blind and Low Vision Users.

Available at: http://www.otal.umd.edu/uupractice/vision/

Accessed December, 2002.

Independent Sector. 2001. The I mpact of I nformation Technology on Civil Society. Facts and Findings, 3 (2).

Available at: http://www.independentsector.org/PDFs/factfind4.pdf

I vory, M., Hearst, M. and Sinha, R. 2001. Empirically Validated Web Page Design Metrics, Proceedings of the ACM SIGCHI '01 Conference: Human Factors in Computing Systems: p. 53-60. New York: ACM.

Kano, N., Seraku, N., Takahashi, F . and Tsuji, S. 1984. Attractive and Normal Quality. Quality, 14 (2): cited by Zhang and von Dran, 2001.

Katerattanakul, P. and Siau, K. 1999. Measuring I nformation Quality of Web Sites: Development of an I nstrument. Proceedings of the Twentieth International Conference on Information Systems: p. 279-285. Charlotte, North Carolina.

Kelsey, B. 2002. IT Strategy and The Internet: A Canadian Perspective. In Hurt, M. E. (ed.), Proceedings of the Annual Conference of the Administrative Studies Association of Canada Winnipeg, MB: ASAC Information Systems Division.

Kerr, G. 2002. Good Enough I nformation Systems. Charity Village. Available at: http://www.charityvillage.com/charityvillage/research/rtech10.htm

King, P. and Tester, J . 1999. The Landscape of Persuasive Technologies. Communications of the ACM, 42: (5) p. 31-38.

Kotler, P. and Zaltman, G. 1971. Social Marketing: An Approach to Planned Social Change, J ournal of Marketing, 35: p. 3-12.

Krehely, J . and Montilla, M. 2001. Equitably Wired? Assessing E-Advocacy Techniques of National Child Advocacy Organizations. The I mpact of Information Technology on Civil Society, Independent Sector Spring Research Forum. Washington, DC.

Lefebvre, R. C. and Flora, J . A. 1988. Social Marketing and Public Health Intervention, Health Education Quarterly, 15 (3), p. 299-315.

Lindenberg, M. 2001. Are We at the Cutting Edge or the Blunt Edge? Improving NGO Organizational Performance with Private and Public Sector Strategic Management Frameworks, Nonprofit Management and Leadership, 11 (3), p. 246-270. 
Lorimer, R. and Gasher, M. 2000. Mass Communication in Canada. Toronto: Oxford.

Lovel ock, C. H. and Weinberg, C. B. 1989. Public and Nonprofit Marketing. Redwood City: The Scientific Press.

Madsen, K. H. 1999. The Diversity of Usability Practices: Introduction, Communications of the ACM, $42(5)$, p. 60-62.

Mcduff, N., Dwyer-Morgan, T. and F rost, K. 2001. Is Technology Transforming the Capacity of Civil Society: Volunteering and the Use of Technology: A Study. ARNOVA. Miami, FL.

National Council of Nonprofit Associations. 1997. A Greater Voice for Nonprofit Organizations. Washington DC: Communications Technology and Advocacy.

Naughton, J . 2001. Contested Space: The Internet and Global Civil Society, Global Civil Society: p. 147-168. London: London School of Economics.

Nielsen, J . and Tahir, M. 2001. Homepage Usability: 50 Web Sites Deconstructed. New Riders.

Nitterhouse, D. 1999. Emerging I nformation Technology Applications for Nonprofit Organizations. ARNOVA. Arlington, VA.

Padanyi, P. and Gainer, B. 2001. Does the I mpact of Market Orientation Vary by Type of Nonprofit Organization?ARNOVA. Miami, FL.

Pargmegiani, M. and Sachdeva, T. 2000. Information and Public Policy Concerning Voluntary Sector Use of Information Technologies, the Internet and the World Wide Web. An International Report.

Available at: http:// www.volnet.org/reports/english/index.html

Park, E. 2001. Net Profits of the Nonprofits. ARNOVA. Miami, FL.

Phelan, J . 1991. Selling Consent: the Public Sphere as the Tel evisual Marketplace in Peter Dahlgren and Colin Sparks (eds.) Communication and Citizenship. London: Routledge..

Pollak, T. and Lampkin, L. 2001. How Technology Is Changing the Role of Nonprofit U mbrella Associations. The I mpact of I nformation Technology on Civil Society, Independent Sector Spring Research Forum. Washington, DC.

Porter, M. 2001. Strategy and the Internet, Harvard Business Review, March. p. 63-78.

Princeton Survey Research Associates. 2001. Wired Willing and Ready: Nonprofit Human Services Organizations' Adoption of Information Technology.

Prives, D. 2000. Accountability Web Site: More Harm Than Good? The Chronicle of Philanthropy, XII (19), p. 30-31.

Salamon, L. 2002. The Resilient Sector: The State of Nonprofit America. Snapshots: Research Highlights from the Nonprofit Sector Research Fund.

Saxton, J . and Game, S. 2001. Virtual Promise: Are Charities Making the Most of the Internet Revolution? London: Third Sector. 
Schubert, P. and Dettling, W. 2002. Extended Web Assessment Method (EWAM )-Evaluation of E-Commerce Applications for the Customer's Viewpoint. In Sprague, R. H., J r. (ed.), Proceedings of the 35th Annual Hawai'i I nternational Conference on System Sciences Waikoloa, $\mathrm{HI}$ : IEEE.

Schwartz, P. H. and Christakis, A. N. 2001. Quality of Mental Health Information on the Internet. National Mental Health Association.

Seo, J . J . H. 2002. Reading the Look and Feel: Interface Design and Critical Theories. Available at: http:/ic.media.mit.edu/people/jseo/courses/cms800/final -paper.html Accessed: September 2002.

Servon, L. and Nelson, M. 2000. Creating an I nformation Democracy: The Role of Community Technology Programs and Their Relationship to Public Policy. Nonprofit Sector Research Fund Working Paper. Aspen Institute.

Stewart, W. 1996. The Charity Game: Waste and Fraud in Canada's \$86 billiona-year Compassion I ndustry. Toronto: Douglas and Mcl ntyre.

Voluntary Sector I nitiative (VSI). 2001. I nformation Technology/I nformation Management and the Voluntary Sector: Environmental Scan. Ottawa: VSI.

Voluntary Sector I nitiative (VSI ). 2002. Building a Stronger Voluntary Sector: How the VSI is Making a Difference. Ottawa: VSI.

Zhang, P. and von Dran, G. M. 2001. Expectations and Rankings of Web Site Quality F eatures: Results of Two Studies on U ser Perceptions. In Sprague, R. H., J r. (ed.), Proceedings of the 34th Annual Hawaii International Conference on System Sciences. Maui, HI : IEEE. 


\section{APPENDIX A: LIST OF ORGANIZATIONS INCLUDED IN ANALYSIS}

\begin{tabular}{|c|c|c|}
\hline Organization & Category & URL \\
\hline AIDS Committee of Toronto & health & http://www.actoronto.org \\
\hline Alcohol and Drug Concerns Inc. & health & http://www.concerns.ca \\
\hline Alliance for Employment Equity & $\begin{array}{l}\text { equality } \\
\text { seeking/human } \\
\text { rights }\end{array}$ & http://www.Web.net/ all foree \\
\hline Alzheimer Society of Canada & health & http://www.alzheimer.ca \\
\hline Amnesty International Canada & $\begin{array}{l}\text { equality } \\
\text { seeking/human } \\
\text { rights }\end{array}$ & http://www.amnesty.ca \\
\hline Anglican Church of Canada, General Synod & faith & http://www.anglican.ca \\
\hline APEC Alert! & political & http://www.cs.ubc.ca/spider/fuller/apec_alert \\
\hline Arthritis Society, National Office & health & http://www.arthritis.ca \\
\hline $\begin{array}{l}\text { Association for the Neurologically Disabled } \\
\text { of Canada }\end{array}$ & health & http://www.and.ca \\
\hline Association of F undraising Professionals & other: fundraising & http://www.afpnet.org \\
\hline Association Resource Centre (ARC) Inc. & other: consultant & http://www.associationconsultants.com \\
\hline Asthma Society of Canada & health & http://www.asthma.ca \\
\hline Big B rothers and Sisters of Canada & $\begin{array}{l}\text { youth services and } \\
\text { support }\end{array}$ & http://www.bbsc.ca \\
\hline Boys and Girls Clubs of Canada & $\begin{array}{l}\text { youth services and } \\
\text { support }\end{array}$ & http://www.bgccan.com \\
\hline Brain Tumor F oundation of Canada & health & http://www.btfc.org \\
\hline Breast Cancer Society of Canada & health & http://www.bcsc.ca \\
\hline Builders Without Borders & social support & http://www.landcentre.ca/builders/ \\
\hline Campaign Life Coalition & political & http://www.lifesite.net/clc \\
\hline Canada Council for the Arts. & arts & http://www.canadacouncil.ca \\
\hline Canada Dance Festival & arts & http://www.canadadance.ca \\
\hline Canada Family Action Coalition & political & http://www.familyaction.org \\
\hline CANADA Literacy Foundation & education & http://www.abc-canada.org \\
\hline Canada Tree & arts & http://www.canadatree.com \\
\hline Canada West Foundation & research & http://www.cwf.ca \\
\hline $\begin{array}{l}\text { Canada World Youth /J eunesse Canada } \\
\text { Monde }\end{array}$ & $\begin{array}{l}\text { youth services and } \\
\text { support }\end{array}$ & http://www.cwy-jem.org \\
\hline Canadian AIDS Treatment Information & health & http://www.catie.ca \\
\hline Canadian Arctic Resources Committee & environment & http://www.carc.org \\
\hline Canadian Association of F ood Banks & health & http://www.icomm.ca/cafb \\
\hline Canadian Celiac Association & health & http://www.celiac.ca \\
\hline
\end{tabular}




\begin{tabular}{|c|c|c|}
\hline Organization & Category & URL \\
\hline Canadian Children's Book Centre & education & http://www.bookcentre.ca/ \\
\hline Canadian Conference of the Arts & arts & http://www.ccarts.ca \\
\hline $\begin{array}{l}\text { Canadian Council for International Co- } \\
\text { operation }\end{array}$ & devel opment & http://www.Web.net/ccic-ccai \\
\hline Canadian Council on Social Development & development & http://www.ccsd.ca \\
\hline Canadian Environmental Law Association & environment & http://www.cela.ca \\
\hline Canadian Environmental Network & environment & http://www.cen-rce.org \\
\hline Canadian Health Coalition & health & http://www.healthcoalition.ca \\
\hline Canadian National Institute for the Blind & social support & http://www.cnib.ca/index.htm \\
\hline Canadian Nature Federation & environment & http://www.chf.ca \\
\hline Canadian Opera Company & arts & http://www.coc.ca \\
\hline Canadian Palliative Care Association & health & http://www.cpca.net/home.htm \\
\hline Canadian Parks and Wilderness Sociey & environment & http://www.cpaws.org/ \\
\hline Canadian Parks Partnership & environment & $\begin{array}{l}\text { http://www.canadianparkspartnership.ca/English/CC } \\
\text { Pframeset.htm }\end{array}$ \\
\hline Canadian Peace Alliance & peace & http://www.acp-cpa.ca \\
\hline Canadian Pediatric Society & health & http://www.cps.ca/english/index.htm \\
\hline Canadian Porphyria F oundation Inc & health & http://www.cpf-inc.ca/ \\
\hline Canadian Race Relations F oundation & $\begin{array}{l}\text { equality seeking/ } \\
\text { human rights }\end{array}$ & http://www.crr.ca/E N/default.htm \\
\hline Canadian Red Cross & health & http://www.redcross.ca/english index.html \\
\hline Canadian Rural Revitalization Foundation & other & http://www.crrf.ca \\
\hline Canadian Society for Asian Arts & arts & http://www.cic.sfu.ca/csaa/ \\
\hline Canadian Society of Association Executives & $\begin{array}{l}\text { other: professional } \\
\text { association }\end{array}$ & http://www.csae.com/ \\
\hline Canadian Special Olympics & other: sports & http://www.cso.on.ca/ \\
\hline Canadian Taxpayers F ederation & political & http://www.taxpayer.com \\
\hline Canadian Unitarian Council & faith & http://www.cuc.ca/ \\
\hline Canadian University College & education & http://www.cauc.ab.ca/ \\
\hline Canadian Women's Foundation & philanthropy & http://www.cdnwomen.org \\
\hline Canadian Women's Health Network & health & http://www.cwhn.ca/indexeng.html \\
\hline $\begin{array}{l}\text { Canadians Concerned About Violence in } \\
\text { Entertainment }\end{array}$ & other: media & $\begin{array}{l}\text { http://www.media- } \\
\text { awareness.ca/eng/med/home/advoc/c-cave.htm }\end{array}$ \\
\hline CARE Canada & social support & http://www.care.ca \\
\hline Careers the Next Generation & employment & http://www.nextgen.org/ \\
\hline Catholic Missions in Canada & faith & http://www.missioncanada.ca/ \\
\hline CAVEAT & justice & http://www.caveat.org \\
\hline Centennial I nfant and Child Centre & $\begin{array}{l}\text { youth services and } \\
\text { support }\end{array}$ & http://www.cicc.on.ca/ \\
\hline
\end{tabular}




\begin{tabular}{|c|c|c|}
\hline Organization & Category & URL \\
\hline Center F or Social J ustice & development & http://www.socialjustice.org \\
\hline Check Your Head & other & http://www.checkyourhead.org \\
\hline Child Find Ontario & $\begin{array}{l}\text { youth services and } \\
\text { support }\end{array}$ & http://www.ontario.childfind.ca/ \\
\hline Children's Aid Foundation & philanthropy & http://www.cafdn.org/index2.html \\
\hline Children's Wish F oundation of Canada & philanthropy & http://www.childrenswish.ca/wishen/home-e.html \\
\hline $\begin{array}{l}\text { Christian Blind Mission I nternational } \\
\text { Canada }\end{array}$ & health & http://www.cbmi-can.org/html/main.htm \\
\hline Christian Children Fund of Canada & $\begin{array}{l}\text { youth services and } \\
\text { support }\end{array}$ & http://www.ccfcanada.ca/home.html \\
\hline Coalition for Gun Control & health/justice & http://www.quncontrol.ca \\
\hline Community Foundation of Canada & social support & http://www.community-fdn.ca/ \\
\hline Community Volunteer Connections & $\begin{array}{l}\text { other: volunteer } \\
\text { association }\end{array}$ & http://www.volunteercentre.org/ \\
\hline Co-Motion & other & http://www.comotionmakers.org \\
\hline Concerned Kids & other: children & http://www.theconcernedkids.com \\
\hline Consumers' Association of Canada & other: consumer & http://www.consumer.ca \\
\hline Council For Canadian Unity & political & http://www.ccu-cuc.ca/index_en.html \\
\hline Council of Canadians & political & http://www.canadians.org \\
\hline Counseling Foundation of Canada & social support & http://www.counselling.net/index.htm \\
\hline Crohn's and Colitis Foundation of Canada & health & http://www.ccfc.ca/en/index.html \\
\hline Curriculum Service Canada (CSC) & education & http://www.curriculum.org/csc/index.htm \\
\hline CUSO & social support & http://www.cuso.org/home.asp \\
\hline David Suzuki Foundation & environment & http://www.davidsuzuki.org \\
\hline Democracy Street & political & http://www.democracy-street.tao.ca \\
\hline Democracy Watch & political & http://www.dwatch.ca \\
\hline Doctor Peter Centre & health & http://www.drpeter.orq/ \\
\hline Donner Canadian Foundation & philanthropy & http://www.donnerfoundation.org/ \\
\hline Ducks Unlimited Canada & environment & http://www.ducks.ca/ \\
\hline Easter Seal Ability Council & social support & http://www.telusplanet.net/public/easter \\
\hline EGALE Canada & $\begin{array}{l}\text { equality } \\
\text { seeking/human } \\
\text { rights }\end{array}$ & http://www.egale.ca \\
\hline Energy Probe & environment & http://www.energyprobe.org \\
\hline Enviro-Coh Enhancement Society & environment & http://www.enviro-coh.org \\
\hline Epilepsy Canada & health & http://www.epilepsy.ca \\
\hline Fair Vote Canada & political & http://www.fairvotecanada.org \\
\hline Families First Resource Society & social support & http://www.familiesfirst.ca \\
\hline F ederation of Ontario Naturalists & environment & http://www.ontarionature.org \\
\hline
\end{tabular}




\begin{tabular}{|c|c|c|}
\hline Organization & Category & URL \\
\hline Forest Action Network & environment & http://www.fanWeb.org \\
\hline Foster Parents Plan & $\begin{array}{l}\text { youth services and } \\
\text { support }\end{array}$ & http://www.fosterparentsplan.ca \\
\hline Foundation for Equal Families & political & http://www.ffef.ca \\
\hline Foundation for Rural Living & social support & http://www.frl.on.ca \\
\hline Fraser Institute & research & http://www.fraserinstitute.ca \\
\hline Friends of Medicare & health & http://www.friendsofmedicare.ab.ca \\
\hline $\begin{array}{l}\text { Friends of the Nelson Mandela Children's } \\
\text { Fund }\end{array}$ & $\begin{array}{l}\text { youth services and } \\
\text { support }\end{array}$ & http://www.cfnmcf.ca \\
\hline Frontier College & education & http://www.frontiercollege.ca \\
\hline Funding Matters I nc. & other: fundraising & http://www.fundingmatters.com \\
\hline Gallery Stratford & arts & http://www.qallerystratford.on.ca \\
\hline Generosity Without Borders Inc. & $\begin{array}{l}\text { other: donation } \\
\text { portal }\end{array}$ & http://www.generositas.com \\
\hline Gideons I nternational In Canada & faith & http://www.gideons.ca \\
\hline Girl Guides of Canada, National Council & $\begin{array}{l}\text { youth services and } \\
\text { support }\end{array}$ & http://www.girlquides.ca \\
\hline Globe Theatre Society & arts & http://www.globetheatrelive.com \\
\hline Greenpeace Canada & environment & http://www.greenpeacecanada.org \\
\hline Habitat for Humanity Canada Inc. & social support & http://www.habitat.ca \\
\hline Heart and Stroke Foundation of Canada & health & http://www.heartandstroke.ca \\
\hline Historica Foundation of Canada & education & http://www.histori.ca \\
\hline Hope for Children Foundation & philanthropy & http://www.ccas.toronto.on.ca \\
\hline Humedica International Canada & health & http://www.humedica.org \\
\hline Hunger Project & social support & http://www.thp.org \\
\hline International Fund for Animal Welfare & environment & http://www.ifaw.org \\
\hline $\begin{array}{l}\text { International Institute for Sustainable } \\
\text { Development }\end{array}$ & development & http://www.iisd.org \\
\hline Invest in Kids Foundation & philanthropy & http://www.investinkids.ca \\
\hline IOF F oresters & $\begin{array}{l}\text { other: fraternal/ } \\
\text { social }\end{array}$ & http://www.iof.org \\
\hline J.W. McConnell Family Foundation & philanthropy & http://www.mcconnellfoundation.ca \\
\hline J ob Skills & employment & http://www.jobskills.org \\
\hline J ohn Howard Society of Canada & justice & http://www.johnhoward.ca \\
\hline J ohn P. Robarts Research Institute & research & http://www.rri.ca \\
\hline Ketchum Canada Inc. & philanthropy & http://www.ketchumcanada.com \\
\hline League of Canadian Poets & arts & http://www.poets.ca \\
\hline MADD Canada & $\begin{array}{l}\text { other health: injury } \\
\text { prevention }\end{array}$ & http://www.madd.ca \\
\hline
\end{tabular}




\begin{tabular}{|c|c|c|}
\hline Organization & Category & URL \\
\hline Max Bell Foundation & philanthropy & http://www.maxbell.org \\
\hline McLean Foundation & philanthropy & http://www.mcleanfoundation.on.ca \\
\hline $\begin{array}{l}\text { Medecins Sans Frontieres (Doctors Without } \\
\text { Borders) }\end{array}$ & health & http://www.msf.ca/ \\
\hline Missionnaires de la Consolata (Canada) & faith & http://www.consolata.org \\
\hline Na'amat Canada, & faith & http://www.naamat.com \\
\hline National Ballet of Canada & arts & http://www.national.ballet.ca \\
\hline National Ballet School & arts & http://www.nbs-enb.on.ca \\
\hline National Firearms Association & political-sports & http://www.nfa.ca \\
\hline Nature Conservancy of Canada & environment & http://www.natureconservancy.ca \\
\hline Non-Smokers' Rights Association & health & http://www.nsra-adnf.ca \\
\hline North-South I nstitute & research & http://www.nsi-ins.ca \\
\hline Ontario Coalition Against Poverty & development & http://www.OCAP.ca \\
\hline $\begin{array}{l}\text { Operation Eyesight Universal World } \\
\text { Headquarters }\end{array}$ & health & http://www.giftofsight.com \\
\hline Operation Springboard & justice & http://www.operationspringboard.on.ca \\
\hline Organization for Quality Education & education & http://www.oge.org \\
\hline Osteoporosis Quebec & health & http://www.osteoporose.qc.ca \\
\hline Osteoporosis Society of Canada & health & http://www.osteoporosis.ca \\
\hline Otonabee Conservation Foundation & environment & http://www.otonabee.com \\
\hline Oxfam Canada & health & http://www.oxfam.ca \\
\hline People for E ducation & education & http://www.peopleforeducation.com \\
\hline Pollution Probe & environment & http://www.pollutionprobe.org \\
\hline Project Ploughshares & peace & http://www.ploughshares.ca \\
\hline $\begin{array}{l}\text { Prostate Cancer Research F oundation of } \\
\text { Canada }\end{array}$ & health & http://www.prostatecancer.on.ca \\
\hline Public Interest Advocacy Centre & political & http://www.piac.ca \\
\hline Rainforest Action Coalition & environment & http://www.ran.org \\
\hline Ruckus Society & other & http://www.ruckus.org \\
\hline $\begin{array}{l}\text { Samuel and Saidye Bronfman Family } \\
\text { Foundation }\end{array}$ & philanthropy & http://www.bronfmanfoundation.org \\
\hline Save Our Sea (Shore) Coalition & environment & http://www.nsis.com/ - egilsson/hereeither.htm \\
\hline Schizophrenia Society of Canada & health & http://www.schizophrenia.ca \\
\hline Scouts Canada, Chinook Region & $\begin{array}{l}\text { youth services and } \\
\text { support }\end{array}$ & http://www.chinook.scouts.ca \\
\hline Sea Shepherd Conservation Society & environment & http://www.seashepherd.org \\
\hline Sierra Club of Canada & environment & http://www.sierraclub.ca \\
\hline Sierra Legal Defence F und & environment & http://www.sierralegal.org \\
\hline
\end{tabular}




\begin{tabular}{|c|c|c|}
\hline Organization & Category & URL \\
\hline Sierra Youth Coalition & environment & http://www.sierrayouthcoalition.org \\
\hline Social I nvestment Organization & $\begin{array}{l}\text { other: ethical } \\
\text { investing }\end{array}$ & http://www.socialinvestment.ca \\
\hline SRS Vocational Services Society & employment & http://www.surreyrehab.bc.ca \\
\hline Street Kids International & development & http://www.streetkids.org \\
\hline Sunshine Dreams for Kids & health & http://www.sunshine.ca \\
\hline Tetra Society of North America & health & http://www.reachdisability.orq/tetra \\
\hline Thalidomide Victims Association of Canada & health & http://www.thalidomide.ca \\
\hline $\begin{array}{l}\text { Third Sector Programme, School of Policy } \\
\text { Studies }\end{array}$ & research & http://www.policy.queensu.ca/sps/ThirdSector/ \\
\hline Tides Canada Foundation & environment & http://www.tidescanada.org \\
\hline $\begin{array}{l}\text { Times Change Women's E mployment } \\
\text { Service }\end{array}$ & employment & http://www.timeschange.org \\
\hline Tourette Syndrome Foundation of Canada & health & http://www.tourette.ca \\
\hline UNICEF Canada & development & http://www.unicef.ca \\
\hline United Church of Canada & faith & http://www.uccan.org \\
\hline United Way of Canada - Centraide Canada & social support & http://www.unitedway.ca \\
\hline Victorian Order of Nurses for Canada & health & http://www.von.ca \\
\hline Volunteer Canada & $\begin{array}{l}\text { Other: volunteer } \\
\text { association }\end{array}$ & http://www.vol unteer.ca \\
\hline Walter and Duncan Gordon F oundation & philanthropy & http://www.gordonfn.org \\
\hline Women's Legal Education and Action F und & $\begin{array}{l}\text { equality seeking/ } \\
\text { human rights }\end{array}$ & http://www.leaf.ca \\
\hline World Federation of Hemophilia & health & http://www.wfh.org \\
\hline World Vision & social support & http://www.worldvision.ca \\
\hline YMCA Canada & social support & http://www.ymca.ca \\
\hline Youth Employment Project & employment & http://www.yepcanada.org \\
\hline Youth Volunteer Corps of Canada & $\begin{array}{l}\text { youth services and } \\
\text { support }\end{array}$ & yvcc.ca \\
\hline YWCA of Canada & social support & http://www.ywcacanada.ca \\
\hline
\end{tabular}

